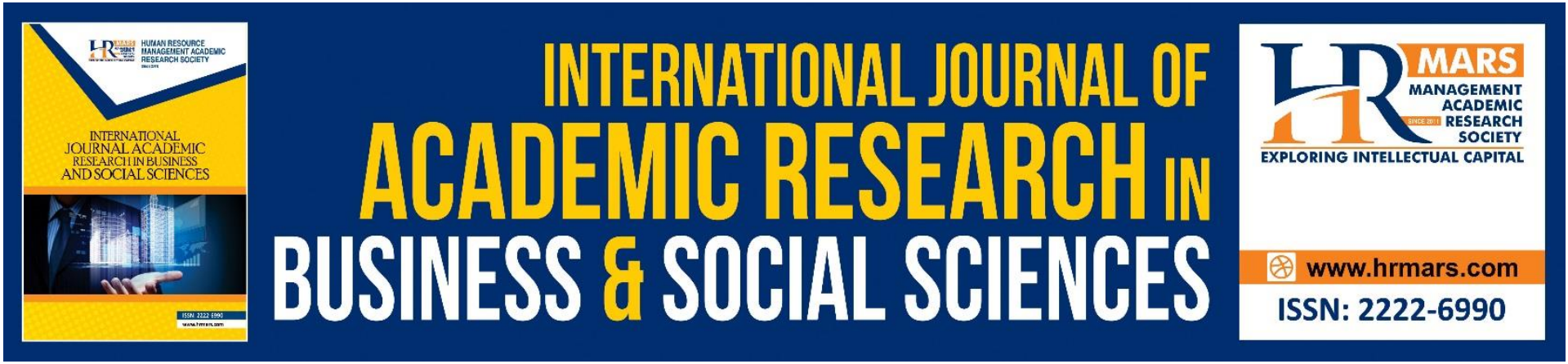

\title{
Examining the Actual Usage of the Port Paperless System (PPS) in Ghana: The Role of Stakeholders
}

James Yaw Osei-Owusu, Rosli Mahmood, Murali Sambasivan

To Link this Article: http://dx.doi.org/10.6007/IJARBSS/v11-i11/11280～DOI:10.6007/IJARBSS/v11-i11/11280

Received: 11 September 2021, Revised: 14 October 2021, Accepted: 25 October 2021

Published Online: 21 November 2021

In-Text Citation: (Osei-Owusu et al., 2021)

To Cite this Article: Osei-Owusu, J. Y., Mahmood, R., \& Sambasivan, M. (2021). Examining the Actual Usage of the Port Paperless System (PPS) in Ghana: The Role of Stakeholders. International Journal of Academic Research in Business and Social Sciences, 11(11), 2355-2373.

Copyright: @ 2021 The Author(s)

Published by Human Resource Management Academic Research Society (www.hrmars.com)

This article is published under the Creative Commons Attribution (CC BY 4.0) license. Anyone may reproduce, distribute, translate and create derivative works of this article (for both commercial and non0-commercial purposes), subject to full attribution to the original publication and authors. The full terms of this license may be seen at: http://creativecommons.org/licences/by/4.0/legalcode

Vol. 11, No. 11, 2021, Pg. $2355-2373$

Full Terms \& Conditions of access and use can be found at http://hrmars.com/index.php/pages/detail/publication-ethics 


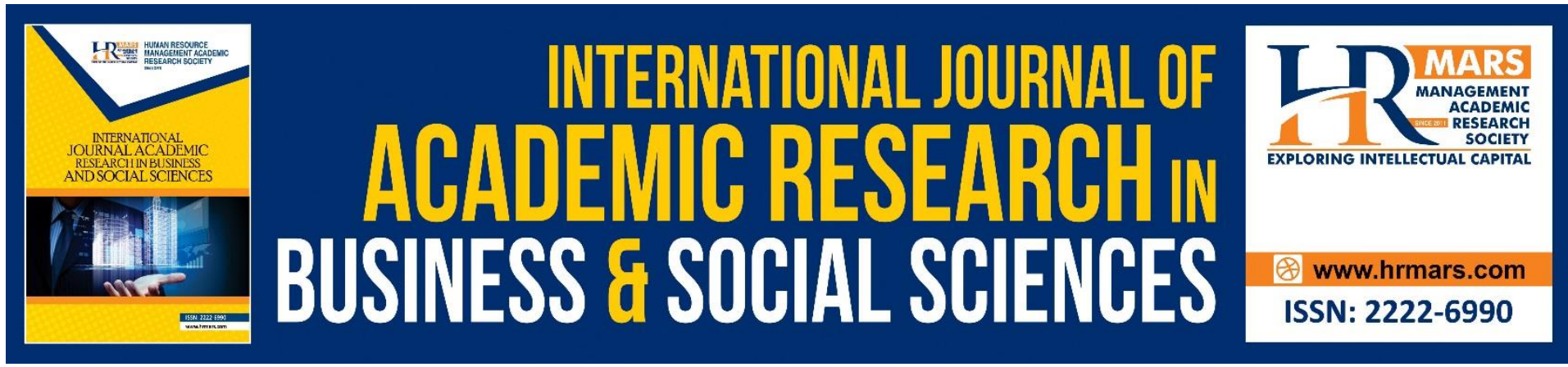

\title{
Examining the Actual Usage of the Port Paperless System (PPS) in Ghana: The Role of Stakeholders
}

\author{
James Yaw Osei-Owusu',2, Rosli Mahmood ${ }^{3}$, Murali \\ Sambasivan 4
}

${ }^{1}$ Putra Business School, Malaysia, ${ }^{2}$ Koforidua Technical University, ${ }^{3}$ Ghana, Putra Business School, Malaysia, ${ }^{4}$ Thiagari Management School, India.

\begin{abstract}
Although the significant role of stakeholders in an organization and institutions are known, nonetheless there is limited literature about them in the shipping industry. This study therefore augments the scanty literature about their role in the maritime industry in a developing country. The United Theory of Acceptance and Use Technology (UTAUT) model 1 was adopted and modified to examine the role of stakeholders in using the Port Paperless System (PPS): a software designed to assists all players in the clearing chain in clearing goods from the ports in Ghana. Data were collected from 336 individuals through the use of a questionnaire and the data analyzed using the Partial Least Square (PLS) statistical tool. Performance expectancy (PE), Effort expectancy (EE), Facilitating conditions (FC) and Stakeholders trust (STR) were confirmed as significant factors in influencing intention to use PPS. Stakeholders knowledge (SK) and Stakeholders training (ST) did not significantly influence intention to use PPS. These findings confirm current research studies conducted at the ports of Ghana and some of the relationships in the UTAUT model and contributes to the growing literature on IS/IT acceptance within the context of an African country.
\end{abstract}

Keywords: Examining, Port Paperless System, Actual Usage, Stakeholders, Ghana.

\section{Introduction}

Ghana has two main seaports namely; Tema port which is the biggest and located in the capital town of Ghana and Takoradi port located within the Western part of Ghana. The ports of the

Rotterdam, Singapore, Mombasa, Cotonou including the ones mentioned above from Ghana and many others from the world play a very vital role towards the socio - economic development of nations, hence various government attach a lot of significance and adherence towards their operations. The port of Tema for instance is responsible for almost $70 \%$ of Ghana's seaborne trade and $35 \%$ of its export. The Takoradi port on the other hand is responsible for handling exports of minerals mainly from the mines situated in the Western part of Ghana (Owusu et al., 2017).

The Rotterdam port and Maritime Singapore all contribute $10 \%$ and $7 \%$ to the GDP of their respective countries with the port of Singapore employing over 170,000 individuals. The port of Mombasa in Kenya admittedly also contribute about $40 \%$ of revenue from imports and 
exports (Mwajita, 2016). The aim of going paperless was to eradicate some of the issues associated with paper centric regime at the ports namely, corruption and bribery, lack of transparency, delays, and bureaucracy and help increase the revenue of the government (Amegboe, 2019; Atehnjia et al., 2020).

The concept of paperless system is not new in the world as it has been applied in diverse field of study. In supply chain management (Osei- Owusu, 2019), e-procurement (Sambasivan, Wemyss \& Che, 2010), education (Atuguffio, 2019) marketing (Al- Qeisi, 2015) and banking (Rahi et al., 2017), however much of it has not been seen in the maritime sector.

Also, what we know is that Ghana has a paperless system for clearing goods at her ports which was introduced in 2017 and that it was characterized with a lot of challenges and hindrances at the introductory stage and after the kick off. What we additionally also know is that the partners of the port, otherwise known as stakeholders who were supposed to support its introduction rather played numerous negative roles in frustrating and sabotaging the establishment of the port paperless system before and after its introduction at the ports of Ghana.

It is important to know that the PPS was established to curtail some of the numerous challenges that had bedeviled the operations of the ports in Ghana Since 1990 such as corruption, bureaucracy, lack of transparency, delay in clearing goods and ensure a regime of transparency devoid of corruption and bribery where every individual can trace the stage of clearance of goods at the ports without any interference. All with the ultimate aim of increasing the revenue of the government.

The intriguing question therefore is why would stakeholders who are supposed to be partners to any entity, company or organization frustrate and sabotage any policy or system put in place to enhance transparency and lead to income generation. Subsequently, this study intends to address this question and unravel the significance of stakeholders' knowledge, trust and training in a port paperless environment.

The contribution of this study comes in three segments; first we have modified the UTAUT model to include stakeholders' concept in terms of knowledge, trust and training. Few studies have outlined the importance of one or two of the variables, for instance trust (Alshehri, 2012; Al-Qeisi, 2015), knowledge and training (Amegboe, 2019). This study is generally the first ever to combine the three variables to study the PPS in Ghana. This study is also conducted in Ghana, an emerging African country and thus validate the UTAUT model since the model was initially used in a Western country and finally, the model in this study is one of the few designed to examine the role of stakeholders in any port paperless environment.

The next section discusses relevant literature related to stakeholders in Ghana. Research methodology, results and discussion is next followed with conclusion which brings the curtains on the entire study to a finality.

\section{Literature Review}

\section{Stakeholders of Ghana's Maritime Industry}

The stakeholders of Ghana's maritime industry can be generally grouped into two that is those who worked directly at the ports or provide direct services from the ports to individuals namely; workers of Ports and Harbor Authority (GPHA), Government Revenue Authority (GRA)- Customs, officiating banks e.g. Ghana Commercial Bank (GCB). Freight forwarders, clearing agents, shipping lines and agents and those whose work are influenced by the actions and activities done or carried out by the ports namely; shippers' council, importers and exporters and Municipal District Assemblies (MDA's) which include, the Food and Drugs 
Authority (FDA), the Ghana Standard Authority (GSA), the Ministry of Food and Agriculture (MOFA), the Ministry of Defense (MOD) and National Security and National Investigation Bureau (NIB). There could be many stakeholders involved but these ones listed above have been chosen because they are directly or indirectly involved with the usage of the port paperless system at the ports of Ghana. As opined by Mikalsen (2001), stakeholders' structure is usually influenced by the area of activities.

GPHA was established in 1986 and mandated by law as a statutory entity to manage, build, plan and control the operations of the two ports in Ghana in collaboration with other key institutions. Its vision is to become one of the leading and efficient maritime hub and preferred port within the Africa continent specifically, West Africa (Amegboe, 2019).

Freight forwarders are those individuals who act as intermediary between the importer and the ports. Ghana Institute of Freight Forwarders (GIFFS), Freight Forwarders Association of Ghana (FFAG), Association of Customs House Agents in Ghana (ACHAIG) and the Customs Brokers Association of Ghana (CUBAG) are few examples in Ghana.

The MDA's are basically workers drawn from the various ministries in Ghana and stationed at various vantage points at the ports of Ghana to ensure compliance with the PPS and also ensure that individuals involved in importing and exporting comply with the various procedures and standards outlined by the government of Ghana. Examples include all those mentioned above.

The Ghana Shippers Authority (GSA) listed about 32 shipping lines in Ghana in 2018 and they operate in both seaports in Ghana. They provide employment, help in increasing the revenue of the government through payment of various taxes and also help in the import and export activities in the country thus helping to increase the foreign exchange generation of the country.

The Ghana Shippers' Authority (GSA) was established in 1974 by the NRCD degree of 254 and has been the main body championing the activities of the Ghana maritime industry. Over the years GSA has collaborated with both public and private companies to undertake its main role of projecting and advancing the goal of shippers in Ghana.

\section{Technological Adoption}

Technological models such as the Theory of Reasoned Action (TRA) (Ajzen and Fisbein, 1975), the Theory of Planned Behavior (TPB) (Ajzen,1991), Technology Acceptance Model (TAM) (Davis,1989), combine TAM and TPB (Taylor and Todd,1995), Innovation Diffusion Theory (IDT) (Rogers,1985), Motivation Model (MM) (Deci and Ryan,1985), Social Cognitive Theory (SCT) (Bandura 1986) and Model of PC Utilization (MPCU) (Triandis, 1979) have all been used in explaining most technological studies or research. These theories have their own limitations and challenges thus averting their individual usage by respective researchers. One greatest limitation associated with all the above mentioned eight technological models is that they have a very low variance of use behavior. In fact, they are only able to account for almost less than 50 percent of the variance of use behavior. Subsequently, the UTAUT model developed by Venkatesh Morris, Davis \& Davis (2003) which is an integration of the above eight technology acceptance models (TRA, TPB, C-TAM-TPB, TAM, IDT, SCT and MM) into one is adopted to address most of the challenges associated with the above eight technology models. In the UTAUT model, the constructs of the eight models are consolidated into four (4) which are, PE, EE, SI and FC. The four moderators of these constructs are gender, age, voluntariness of use and experience. 
The UTAUT model has high prediction of user intention as compared to previous IS and IT models which only predicted or explained 40 percent of user acceptance. UTAUT is able to predict 70 percent of user acceptance thus having a high variance. Additionally, the parsimonious nature of the UTAUT model makes it highly preferable as compared to the other technology models. Parsimonious theories connote higher degrees of freedom which gives them the impulse to be more conducive to other settings, contexts and populations.

Finally, the robustness nature of the UTAUT model makes it more imperative to be chosen over the other IT/IS models. The robustness nature of the model gives it the power, strength, capacity and vigor to predict user intention or acceptance under any given situation. Therefore, this study adopts the UTAUT model with some variations for studying the actual usage of the port paperless system in Ghana. This will be followed by a discussion on the study model (UTAUT) and the respective hypotheses formulated based on the study model.

\section{Research Model and Hypotheses}

A lot of technological adoption models and for that matter UTAUT have not been tested extensively in developing economies (Abu- Shanab and Pearson, 2009) and in Africa particular, it is therefore important to expand the model to cover other areas in order to obtain acceptance findings (Bagozzi, 2009), even though a lot of studies have adopted it to interrogate behavior acceptance in many environment (Osei Owusu, Mahmood and Sambasivan, 2020; Yakubu and Dasuki, 2018). Additionally, some studies have modified the UTAUT model to include new constructs such as trust (Alshehri, 2012), training (Amegboe, 2019) and education (Attuquiffo, 2019). Since the inception of the port paperless system in Ghana four years ago, no study has adopted the UTAUT model to portray its significance to the Ghanaian economy and the world at large. Refer to table 1 below for a discussion on the constructs outlined in the modified UTAUT (see Figure 1) adopted for the study. 
Figure 1: Research model (Conceptual framework)

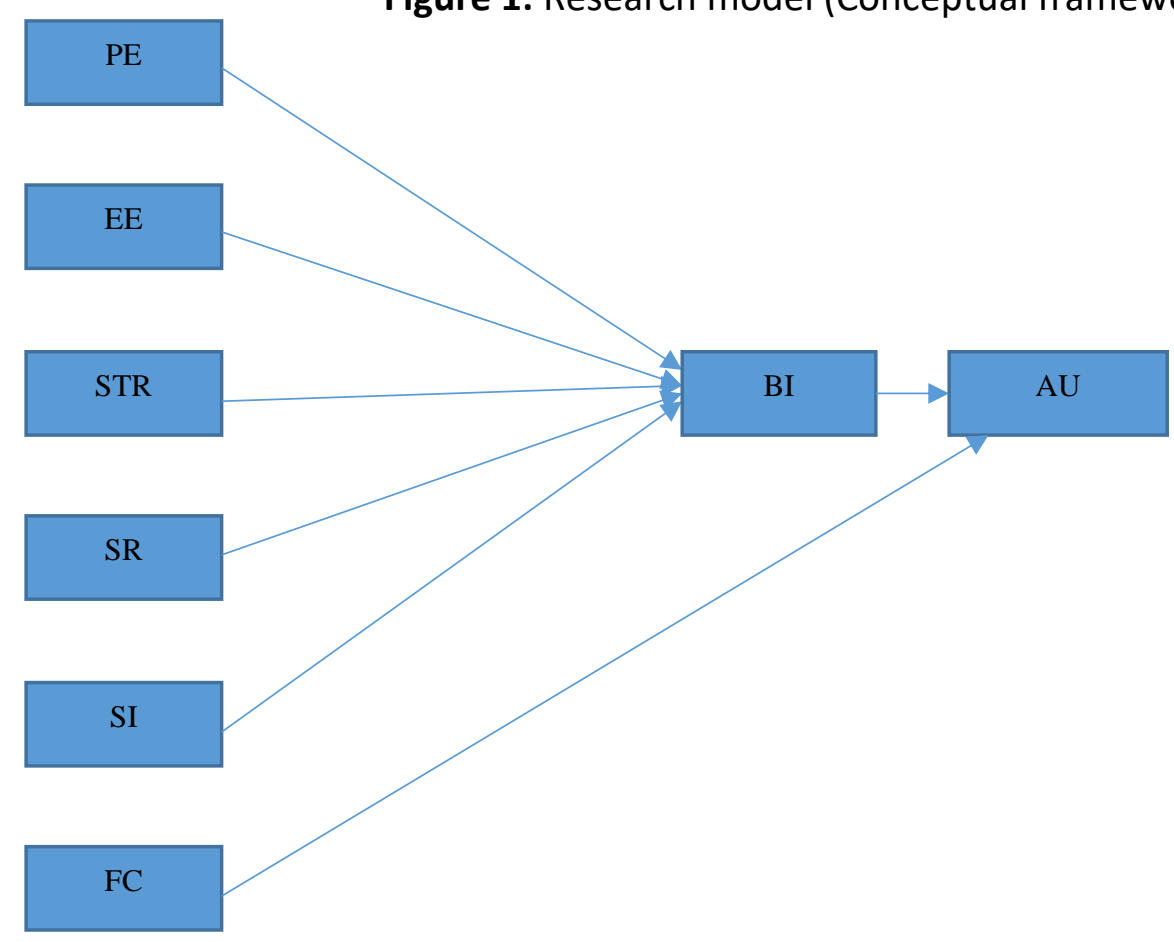

$\underline{K E Y}$

PE - Performance Expectancy

EE- Effort Expectancy

STR-Stakeholders Trust

SK- Stakeholders Knowledge

ST- Stakeholders Training

FC- Facilitating Conditions

BI- Behavioral Intention

AU- Actual Usage

\section{Performance Expectancy}

PE refers to the propensity that using a system will help individuals attain gains in job performance. This construct is the same as perceived usefulness in the TAM model and also in the combined TAM-TPB. It is also the same as extrinsic motivation in the MM, relative advantage in the IDT, job fit in the MPCU and finally outcome expectancy in the SCT. According to Venkatesh et al (2003), the PE construct was the strongest predictor of intention amongst all the independent variables in both mandatory and voluntary environments. A lot of studies have shown both positive (Wiafe, Koranteng, Tettey, Kastriku, \& Abdulai, 2019) and negative (Enrique, Achman, Tulus) findings with the PE construct under different sectors in different environment. The relationship between $\mathrm{PE}$ and $\mathrm{BI}$ has shown mixed findings. Therefore, due to the in consistency in the findings, there is the need to further investigate the PE variable in the port paperless environment in Ghana. In view of this the research hypothesis related to the PE variable will be posit as;

H1. PE has a positive impact on an individual's BI to use the PPS within the shipping industry in Ghana. 


\section{Effort Expectancy}

EE refers to the propensity associated with the ease of use of a particular system. Effort expectancy is equivalent or the same as complexity in the MPCU and IDT as well as perceived ease of use in the TAM model. Therefore, it is expected that when the users of Ghana's port paperless system find it so comfortable in using the new system for their port transaction, then they are likely to adopt to its usage. Effort expectancy has also been used as a construct in different research areas and location some showing positive (Naranjo-Zolotov, Oliveria and Castelyn, 2019) and negative (Goularte and Zilber, 2019) connotations. Therefore, owning to the mixed findings and non- availability of literature to illustrate it within the shipping industry in Ghana, there is need to further investigate this EE construct within the port paperless environment in Ghana. In view of this, the research hypothesis related to the EE variable will be posit as:

H2. EE has a positive impact on an individual's BI to use the PPS within the shipping industry in Ghana.

\section{Facilitating Conditions}

FC refer to propensity that there exist organizational and technical infrastructure to support the use of a system. This construct is the same as compatibility in the IDT and likewise facilitating conditions in the MPCU. Perceived behavioral control in the combined TAM- TPB and DTPB / TPB is the same as facilitating conditions. In the UTAUT 1 model, developed by Venkatesh et al (2003), the FC construct was the only independent variable that had it effect shown on the used behavior, that is the dependent variable. All other independent variables namely; PE, EE and SI had their effort shown on the BI construct. The reason been that any time $P E$ and EE are present the effect of FC is not shown. This is because the EE fully mediates the relationship between $\mathrm{FC}$ and $\mathrm{BI}$. A lot of studies though not in the maritime sector have shown a positive relationship between the FC construct and actual usage (Rahi, et al, 2019) and others, a negative relationship (Talal and Zhang 2019). Due to the mixed findings and non-availability of literature to show this relationship within the maritime sector, there is the need to further investigate this relationship in the maritime sector of Ghana. Subsequently, the hypothesis related to this construct is hypothesized as

H3. FC has a positive impact on an individual's BI to use the PPS within the shipping industry in Ghana.

\section{Stakeholders Trust}

According to Rousseau, Sitkin, Burt and Camerer (1998), trust is defined as the willingness of a person to rely on someone or a party due to some beliefs and features upheld by that party. Trust is invariably an essential element in all associations (Montague, 2010). According to Xu, Le, Deitermann and Montague (2014), three different types of trust can be associated with social technological systems. They are technological, interpersonal and institutional trusts. This study focuses on all the three categorizations of trust identified by $\mathrm{Xu}$ et al (2014). Therefore, it is expected that there will be a significant positive relationship with regards to trust and the use of the PPS. Most technological studies have shown a positive significant relationship between trust and actual usage (Alshehri, 2012; Colesca and Dobrica, 2018). Carter and Belanger (2005) on the other hand has also shown that lack of trust in online transactions can be a hindrance in the adoption of an online technology. Subsequently, due to the inconclusiveness associated with the trust construct, there is the need to further interrogate the trust construct on other online studies especially in the maritime sector where 
much has not been done. Therefore, the hypothesis related to the trust construct is hypothesized as;

H4. STR has a positive impact on an individual's BI to use the PPS within the shipping industry in Ghana.

\section{Stakeholders Knowledge}

This basically relates to the accumulated knowledge that stakeholders have acquired with respect to the use of the port paperless system technology (Amegboe, 2019). The GPHA and the owners of the PPS (Ghana link Network services and CUPIA) are expected to provide a whole lot of education and knowledge to all stakeholders of the ports of Ghana to enable them effectively use the new PPS. The. The education received by these stakeholders is expected to systematically help them learn with the ultimate aim of making them acquire knowledge that can help them to effectively use the PPS in all their port transactions. This study therefore intends to find out, four years after the introduction of the PPS, whether the knowledge acquired by these stakeholders through the education given to them before the introduction of the PPS, has effectively enable them to assess the PPS in all their port businesses. Subsequently, the hypothesis related to this construct is hypothesized as;

H5. SK has a positive impact on an individual's BI to use the PPS within the shipping industry in Ghana.

\section{Stakeholders Training}

Training is the systematic procedure associated with the inculcation of some practical skills in an individual to enable the individual perform a specific skills or behavior. ST refers to the training stakeholders receive with respect to how to effectively use the port paperless system. As earlier on stated, the usual practice for the introduction of any software or technology at the ports of Ghana is for GPHA and the owners of the software to provide some form of training for all the stakeholders before the introduction of the said software or technology. This means GPHA and Ghana Link Network Service and their Korean counterparts, CUPIA were supposed to provide some form of training to all prospective stakeholders of the ports in Ghana before the commencement of the PPS some four years ago. This study intends to find out whether the stakeholders have been given enough training since the introduction of the PPS to enable them perform all their port businesses and transactions with ease. Subsequently, the training component variable associated with this study is hypothesized as; H6. ST has a positive impact on an individual's BI to use the PPS within the shipping industry in Ghana.

\section{Behavioural Intention}

According to Krueger (2000) intention depicts an individual's commitment towards a given task and illustrate an individual's wish to tackle a specific task. BI on the other hand is associated with the ability of one to perform or not to perform a specific course of action due to the deliberate intention formed by the individual (Venkatesh et al, 2010). This construct is the same in other technological models such as behavior in SCT, intentions in both IDT and TAM and attitude in TRA. In the TPB, Ajzen (1991) opines that $\mathrm{BI}$ is a fundamental element in depicting the adoption of a new technology and that when one deems the use of a new technology to be useful, that individual develops a positive behavioral intention with respect to that new technology. It is therefore expected that when the users of the PPS find the technology useful, they will develop a positive attitude towards its adoption and actual usage. 
According to Davis et al (1989) behavioral intention influences actual system usage. Therefore, the hypothesis associated with the BI constructs is hypothesized as;

H7. BI to use PPS has a positive impact on an individual's actual usage of PPS within the shipping industry in Ghana.

\section{Methodology}

A written letter seeking for data collection was sent to the Human Resource (HR) department of GPHA and some selected shipping companies located in Tema and the District Secretariat Office of Ghana Institute of Freight Forwarders (GIFFS) in Tema to officially attain the figures of those members of theirs who were involved in the daily operations of the PPS, this is because there is no official record of the actual users of the ports in Ghana. Self-administered questionnaire was the sampling instrument used for the study. The sampling frame was obtained from the above-mentioned entities and the frame listed, 1,555 users across the different mentioned authorities. Research randomizer (Urbaniak, 1997) a random number generated from the internet was randomly used to select 410 users. The questionnaire was sent to all the selected users. A total of 336 questionnaires (respond rate- 82 percent) were collected and used for further analysis using Smart Partial Least Squares (SPLS). Refer to (Table I) for a detailed analysis of the respondents' characteristics.

\section{Development of Measures and pre- test}

The questionnaire consisted of three (3) parts. Part one (1) covered the bio data or personal information section. Part two (2) consisted questions centered on the UTAUT model, that is on all the independent variables. Part 3 handled the questions based on actual usage of the PPS. The scales for PE and EE were adapted from studies on UTAUT (Venkatesh, et al, 2003). The measures for SK and ST were adapted from (Amegboe, 2019). The measures for STR were adapted from Alshehri (2012). The measures for FC and the six independent variables and the dependent variables measuring BI to use PPS and AU behavior were all adapted from studies by Venkatesh et al (2003) and Sambasiva et al (2010). The Likert Scale preferably the FivePoint type were used for all the variables and respondents were asked to indicate their preferences. The Appendix contains a complete list of items under each measure. Twenty (20) of the preliminary version of the questionnaire were tested on selected users at the ports of Ghana in order to ensure some comprehension and reliability of the questions and the twenty selected users were also excluded from the main survey. Some minor changes were affected on the questionnaire before they were sent to the 410 users.

\section{Results and Discussion}

This study adopted the PLS technique specifically (Smart PLS 3.0 software). This is because the main conceptual framework of the study (Figure 2) involves predicting behavior specifically the BI of the users of Ghana's ports in relation to the PPS amongst associations such as PE, EE, SK of the PPS, ST and FC. The adoption of the PLS technique is grounded on the basis that Hair et al (2010) has opined that the ultimate goal of PLS-SEM is to predict the behavior of the relationship among variables and also interrogate the hypothetical model.

\section{Respondents Demographics}

Out of the 410 questionnaire administered after twelve weeks of questionnaire administration, 336 were valid for the analysis ( 82 percent respond rate). The remaining 74 constituting (18 percent non response rate) were all discarded. This is because either a full 
page or more were not completed and in some cases only the bio data section was filled coupled with many that were not also returned. Therefore, in order to avoid bias all such questionnaire were excluded from the final analysis. Out of the 336 respondents, 220 (65.5\%) were male and 116 (34.5\%) were female, thus suggesting that the port business is a male dominated job. $2.1 \%$ (7) of the respondents were either 20 years of age or below, whilst the bulk of the respondents were between the ages of 21-50 representing ninety-two point nine percent (92.9\%) and the least been in the age brackets of 51-60 years representing 20 persons constituting six percent (6\%). Majority of the respondents were educated up to the tertiary level, thus constituting 220 people (65.5\%), followed by 61 individuals who had basic education (18.2\%), fifteen point two percent (15.2\%) for postgraduate and $4(1.2 \%)$ people representing others who had either a professional qualification related to the shipping industry or in maritime engineering. This also shows that the shipping industry is full of individuals who are highly educated. The study also revealed that freight forwarders or forwarding agents are the majority of individuals who work at the ports in Ghana. They constitute 139 individuals (41.4\%), this is followed by shipping lines and agents $84(25.0 \%)$, workers of the ports (GPHA) - 17.9\% (60), declarants - 30 (8.9\%), GRA-customs - $2.7 \%$ (9), MDA's - $6(1.8 \%)$ and collecting banks and shippers' council all having 4 respondents each with a percentage of one point two each (1.2\%). Almost all the respondents had a lot of experience in the shipping industry, this is because 91 (27.1\%) of them had worked at the ports for a duration of $1-5$ years and $72.9 \%$ (245) of them had also worked at the ports for more than five to fifteen years. This in effect means the respondents had so much knowledge and experience to answer the research questions. 
Table 1: Demographics characteristics of respondents

\begin{tabular}{|c|c|c|c|}
\hline No & Items & Frequency & Percentage (\%) \\
\hline 1 & $\begin{array}{cc}\text { Gender } \\
-\quad \text { Male } \\
-\quad \text { Female }\end{array}$ & $\begin{array}{l}220 \\
116\end{array}$ & $\begin{array}{l}65.5 \\
34.5\end{array}$ \\
\hline 2 & $\begin{array}{ll} & \text { Age } \\
- & 20 \text { or Under } \\
- & 21-30 \text { Years } \\
- & 31-40 \text { Years } \\
-\quad & 41-50 \text { Years } \\
- & 51-60 \text { Years }\end{array}$ & $\begin{array}{c}7 \\
70 \\
148 \\
91 \\
20\end{array}$ & $\begin{array}{c}2.1 \\
20.8 \\
44.0 \\
27.1 \\
6.0\end{array}$ \\
\hline 3 & $\begin{array}{l}\text { Educational Level } \\
\text { - } \quad \text { High school or below } \\
\text { - Diploma } \\
\text { - } \quad \text { Bachelor's degree } \\
\text { - } \quad \text { Post graduate degree } \\
\text { - } \quad \text { Others(please specify) }\end{array}$ & $\begin{array}{c}61 \\
98 \\
122 \\
51 \\
4\end{array}$ & $\begin{array}{c}18.2 \\
29.2 \\
36.3 \\
15.2 \\
1.2\end{array}$ \\
\hline 4 & $\begin{array}{l}\text { Which category of group do you } \\
\text { belong to at the port? } \\
-\quad \text { Declarants } \\
-\quad \text { Freight } \\
\text { forwarders/forwarding } \\
\text { agents } \\
-\quad \text { GRA-Customs } \\
-\quad \text { Collecting Banks } \\
\text { - Port authority (Workers of } \\
\text { GPHA) } \\
\text { - Shippers Council } \\
\text { - Shipping lines and agents } \\
-\quad \text { MDA's }\end{array}$ & $\begin{array}{c}30 \\
139 \\
9 \\
9 \\
4 \\
60 \\
\\
4 \\
84 \\
6\end{array}$ & $\begin{array}{c}8.9 \\
41.4 \\
\\
2.7 \\
1.2 \\
17.9 \\
\\
1.2 \\
25.0 \\
1.8\end{array}$ \\
\hline 5 & 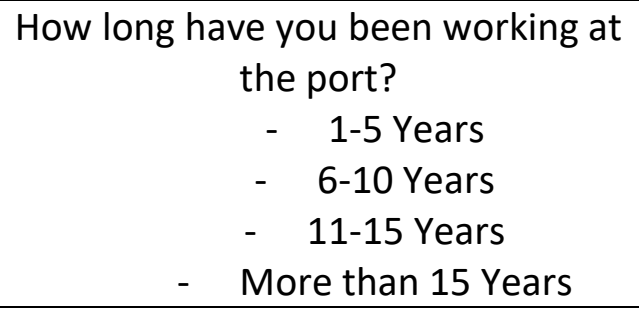 & $\begin{array}{c}91 \\
109 \\
85 \\
51\end{array}$ & $\begin{array}{l}27.1 \\
32.4 \\
25.3 \\
15.2\end{array}$ \\
\hline
\end{tabular}

\section{Reliability and Validity}

Cronbach's Alpha (CA) and Composite Reliability (CR) were both used in testing the reliability of all the constructs. All the constructs conformed to Straub (1989) proposition, that is to say they all had CA and CR loadings greater than 0.7 (Refer to table 2). All item loadings were also greater than 0.7 as opined by (Churchill, 1979). (Refer to table 2). For convergent validity, it is required that AVE values be greater than 0.5 to confirm convergent validity, the results in Table 2 showed that AVE and factor loadings were greater than 0.5 hence the results confirm the constructability to explain over half of the variations of its indicators.

Individual constructs are divergent from other constructs (Hair et al, 2010; Henseler et al, 2016b). To confirm discriminant validity, the diagonal values (square root of AVE) of each 
latent variable should have higher values than its highest correlation of the construct. Thus, the result in Table III supports discriminant validity. The results again confirm the absence of multicollinearity (Byrne, 2013). Additionally, Henseler et al (2015) are of the view that to further confirm the presence of discriminant, the heterotrait-monotrait ratio of correlations (HTMT), which is a multitrait-multi method matrix, ought to be explored to validate the result of the Fornell -Larcker (1981) criterion. Therefore, the HTMT technique was used to test the discriminant validity. According to Kline (2011), to confirm discriminant validity, the HTMT value should not be more than 0.85 . Gold et al (2001) on the other hand is of the view that the HTMT value should not be more than 0.90 to confirm discriminant validity. The result as presented in Table 4 indicates that all the values passed the HTMT 0.90 (Gold et al, 2001). Consequently, using both the Fornell and Larcker (1981) criterion and the heterotraitmonotrait ratio of correlations (HTMT), the results indicate that discriminant validity was realized. The collinearity statistics (VIF) displayed in Table 2 also showed ideal collinearity statistics (VIF< 3) (Hair et al, 2019). Collinearity arises when two indicators are highly correlated.

Table 2: Validity and Reliability

\begin{tabular}{|c|c|c|c|c|c|c|}
\hline Construct & Items & Loadings & $\begin{array}{l}\text { Cronbach's } \\
\text { Alpha (CA) }\end{array}$ & CR & AVE & VIF \\
\hline \multirow[t]{4}{*}{ Actual Usage } & AU1 & 0.864 & 0.895 & 0.927 & 0.761 & 2.154 \\
\hline & AU2 & 0.893 & & & & 2.234 \\
\hline & AU3 & 0.863 & & & & 2.178 \\
\hline & $\mathrm{AU} 4$ & 0.868 & & & & 1.88 \\
\hline \multirow[t]{4}{*}{ Behavioral Intentions } & BI1 & 0.848 & 0.930 & 0.950 & 0.828 & 1.616 \\
\hline & BI2 & 0.922 & & & & 2.242 \\
\hline & $\mathrm{BI} 3$ & 0.931 & & & & 1.268 \\
\hline & BI4 & 0.936 & & & & 1.848 \\
\hline \multirow[t]{4}{*}{ Effort Expectancy } & EE1 & 0.902 & 0.923 & 0.945 & 0.813 & 1.848 \\
\hline & EE2 & 0.893 & & & & 1.703 \\
\hline & EE3 & 0.924 & & & & 2.107 \\
\hline & EE4 & 0.886 & & & & 2.24 \\
\hline \multirow[t]{4}{*}{ Facilitating Condition } & FC1 & 0.819 & 0.856 & 0.903 & 0.699 & 1.754 \\
\hline & $\mathrm{FC2}$ & 0.844 & & & & 2.237 \\
\hline & FC3 & 0.886 & & & & 1.082 \\
\hline & FC4 & 0.792 & & & & 1.223 \\
\hline \multirow[t]{4}{*}{ Performance Expectancy } & PE1 & 0.893 & 0.931 & 0.951 & 0.828 & 2.65 \\
\hline & PE2 & 0.930 & & & & 2.654 \\
\hline & PE3 & 0.896 & & & & 2.326 \\
\hline & PE4 & 0.920 & & & & 1.03 \\
\hline \multirow[t]{4}{*}{ Stakeholder Knowledge } & SK1 & 0.925 & 0.741 & 0.751 & 0.602 & 2.897 \\
\hline & SK2 & 0.951 & & & & 1.417 \\
\hline & SK3 & 0.924 & & & & 2.568 \\
\hline & SK4 & 0.840 & & & & 1.081 \\
\hline \multirow[t]{2}{*}{ Stakeholder Training } & STR2 & 0.748 & 0.731 & 0.867 & 0.768 & 2.449 \\
\hline & STR4 & 0.803 & & & & 2.395 \\
\hline \multirow[t]{2}{*}{ Stakeholder Trust } & ST3 & 0.785 & 0.931 & 0.951 & 0.830 & 2.499 \\
\hline & ST4 & 0.959 & & & & 2.921 \\
\hline
\end{tabular}


Table 3: Heterotrait-Monotrait Ratio (HTMT)

\begin{tabular}{|c|c|c|c|c|c|c|c|c|}
\hline Construct & 1 & 2 & 3 & 4 & 5 & 6 & 7 & 8 \\
\hline $\begin{array}{l}\text { Actual } \\
\text { Usage }\end{array}$ & & & & & & & & \\
\hline $\begin{array}{l}\text { Behavioral } \\
\text { Intentions }\end{array}$ & 0.704 & & & & & & & \\
\hline $\begin{array}{c}\text { Effort } \\
\text { Expectancy }\end{array}$ & 0.801 & 0.830 & & & & & & \\
\hline $\begin{array}{l}\text { Facilitating } \\
\text { Condition }\end{array}$ & 0.787 & 0.849 & 0.506 & & & & & \\
\hline $\begin{array}{c}\text { Performance } \\
\text { Expectancy }\end{array}$ & 0.665 & 0.841 & 0.816 & 0.800 & & & & \\
\hline $\begin{array}{c}\text { Stakeholder } \\
\text { Knowledge }\end{array}$ & 0.051 & 0.084 & 0.064 & 0.110 & 0.132 & & & \\
\hline $\begin{array}{c}\text { Stakeholder } \\
\text { Training }\end{array}$ & 0.062 & 0.046 & 0.029 & 0.031 & 0.057 & 0.834 & & \\
\hline $\begin{array}{c}\text { Stakeholder } \\
\text { Trust }\end{array}$ & 0.688 & 0.880 & 0.838 & 0.826 & 0.821 & 0.063 & 0.047 & \\
\hline
\end{tabular}

An assessment of both the total effects and its respective sizes were analyzed as shown in Table 4. According to Cohen (1988) the $p$ values determine the sizes of an effect, nonetheless it is not able to show the exact quantum of the effect. Values of $0.02,0.15$ and 0.35 of effect size $\left(f^{-2}\right)$ path co-efficient depicts small, medium and large. Table 4 depicts values for $f^{2}$. The cross - validated redundancy was also explored relying on the blindfolding technique to validate the models predictive relevance $\left(Q^{2}\right)$. Chin, $(1998 a, b)$ and Henseler et al (2009) opine that $Q^{2}$ value should be above zero. The results are shown in Table 4. Falk \& Miller (1992) opines that for the acceptance of a models predictive relevance, the $\mathrm{R}^{2}$ should be greater than 0.10 . The model in this study shows substantial predictive accuracy ( $R^{2}$ adjusted) values of 0.713 towards Actual Usage and 0.690 toward behavioural intentions as shown in Table 4.

Table 4: Total effect with effects size, Stone-Geisser Coefficient.

\begin{tabular}{|c|c|c|c|c|}
\hline$f^{2}$ & & & $\mathbf{Q}^{2}$ & $\mathbf{R}^{2}$ \\
\hline & $A U$ & B1 & 0.521 & 0.690 \\
\hline$P E$ & & 0.115 & 0.609 & 0.713 \\
\hline $\mathrm{EE}$ & & 0.061 & & \\
\hline SK & & 0.000 & & \\
\hline STR & & 0.230 & & \\
\hline ST & & 0.001 & & \\
\hline FC & 0.035 & & & \\
\hline $\mathrm{BI}$ & 0.702 & & & \\
\hline$A U$ & & & & \\
\hline
\end{tabular}

\section{Structural Model and Hypothesis Testing}

The hypothesis of the study was tested using smart PLS. The following inferences were made from the outputs. $\mathrm{H}_{1}$ which establishes the link between $\mathrm{PE}$ and $\mathrm{BI}$ is strongly supported $(\beta=0.292, t=4.136, P<0.05)$. This confirms hypothesis 1 of the study as well as objective 1 . This 
also implies that if stakeholders perceive a high level of usefulness of PPS, the BI to use PPS will be high. $\mathrm{H}_{2}$ which posits a positive relationship between EE and $\mathrm{BI}$ to use PPS is strongly supported $(\beta=0.214, t=4.136, P<0.05)$. This results also confirms objective 2 of the study. This implies that if users perceive that PPS is easy to use, the $\mathrm{BI}$ to use the system will be high. $\mathrm{H}_{3}$ which establishes the relationship between STR and BI to use the PPS is strongly supported $(\beta=0.428, t=7.122, P<0.05)$. This finding confirms both objective 3 and hypothesis 3 of the study. This implies that if the users of the PPS view that technologically, they are safe in terms of using the PPS and that the people also involved in using the system can be trusted, then the $\mathrm{BI}$ to use the system will be high. $\mathrm{H}_{4}$ posit the link between SK of the PPS and $\mathrm{BI}$ to use the PPS was not supported. $\mathrm{H}_{5}$ which establishes the relationship between ST and BI to use the PPS was also not supported. This equally means objective 5 and hypothesis 5 are not confirmed in the study. $\mathrm{H}_{6}$ which posits the relationship between FC and AU of the PPS is strongly supported by $(\beta=0.162, t=3.347, P<0.05)$. This means both objective 6 and hypothesis 6 are confirmed in the study. This also implies that if the government and GPHA put in much technical and infrastructure support to make the use of the PPS conducive, the AU of the PPS will be high. $\mathrm{H}_{7}$ which establishes the relationship between $\mathrm{BI}$ and $\mathrm{AU}$ of the PPS is strongly supported $(\beta=0.704, t=15.918, P<0.05)$. This equally means both objective 7 and hypothesis 7 are confirmed in the study and it also implies that BI to use PPS translates into AU of PPS by the users.

In summary, the variables that influence the BI to use PPS by the stakeholders are, PE, EE and STR with FC influencing AU of the PPS. SK of the PPS and ST did not influence the BI of the stakeholders to use the PPS. The variable, BI influences AU of the PPS. A summary of the paths analysis is shown in Table 5 and the PLS results also shown in figure 2.

Table 5: Structural Model and Hypotheses Testing

\begin{tabular}{|l|l|l|l|l|l|}
\hline Hypotheses & $\begin{array}{l}\text { Path } \\
\text { Coefficient }\end{array}$ & StD & $\begin{array}{l}\text { T } \\
\text { Statistics }\end{array}$ & $\begin{array}{l}\text { P } \\
\text { Values }\end{array}$ & Results \\
\hline $\begin{array}{l}\text { Behavioral Intentions -> } \\
\text { Actual Usage }\end{array}$ & 0.704 & 0.044 & 15.918 & 0.000 & Supported \\
\hline $\begin{array}{l}\text { Effort Expectancy } \\
\text { Behavioral Intentions }\end{array}$ & 0.214 & 0.052 & 4.136 & 0.000 & Supported \\
\hline $\begin{array}{l}\text { Performance Expectancy } \\
\text {-> Behavioral Intentions }\end{array}$ & 0.292 & 0.061 & 4.793 & 0.000 & Supported \\
\hline $\begin{array}{l}\text { Stakeholder Knowledge - } \\
\text { > Behavioral Intentions }\end{array}$ & 0.018 & 0.031 & 0.365 & 0.716 & $\begin{array}{l}\text { Not } \\
\text { Supported }\end{array}$ \\
\hline $\begin{array}{l}\text { Stakeholder Training -> } \\
\text { Behavioral Intentions }\end{array}$ & -0.024 & 0.031 & 0.654 & 0.513 & $\begin{array}{l}\text { Not } \\
\text { Supported }\end{array}$ \\
\hline $\begin{array}{l}\text { Stakeholder Trust -> } \\
\text { Behavioral Intentions }\end{array}$ & 0.428 & 0.060 & 7.122 & 0.000 & Supported \\
\hline $\begin{array}{l}\text { Facilitating Condition -> } \\
\text { Actual Usage }\end{array}$ & 0.162 & 0.047 & 3.347 & 0.001 & Supported \\
\hline
\end{tabular}


Figure 2: Results of the analysis of the research model.

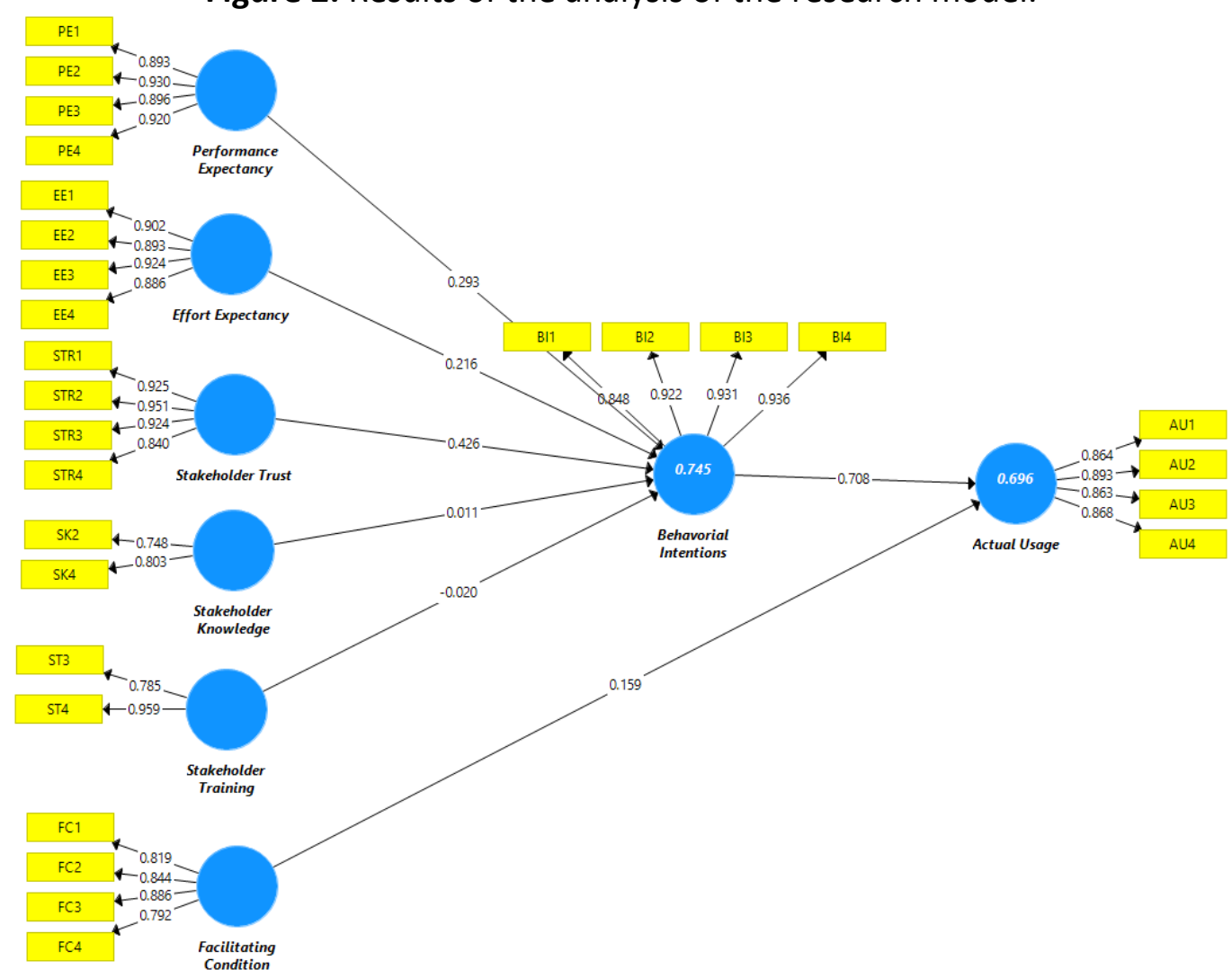

\section{Conclusion}

This study started with an alluring topic; Ghana's port paperless System: the role of stakeholders. Here the role of stakeholders in terms of knowledge they have with regard to PPS, training they have received before, the commencement of the PPS as well as the trust they have with respect to the usage of the PPS and the people controlling its operations were all delved into. Additionally, the UTAUT constructs namely PE that connotes efficiency, EE that also connotes ease of use and FC that postulates the availability of technical and physical infrastructural were all exploited and the hypothesis for the study developed from all the above-mentioned constructs.

The UTAUT Model developed by Venkatesh et al (2003) with a simple extension has been found to be appropriate to address the research questions outlined in this study. PE, EE and FC associated with the UTAUT constructs were maintained, whilst STR, knowledge of the PPS and training were incorporated from previous research work. The PLS-SEM statistical tool was used for the analysis of the entire study and the findings confirm UTAUT as doing a good job by integrating various model (Sambasivan et al, 2010). The importance of the UTAUT model in terms of high variance, parsimonious and robustness were all shown in the study as the model accounted for 69 percent of variation of $\mathrm{BI}$ and 71 percent of $\mathrm{AU}$ in explaining technology acceptance and use in a developing country. The study confirmed three constructs of predicting BI to use the PPS (PE, EE and STR). One in predicting AU of the PPS (FC) with two not been able to predict BI to use the PPS (SK and ST).

Many studies have empirically tested the link between $\mathrm{PE}$ and $\mathrm{BI}$ and the finding of this study is consistent with their results (Wiafe, et al., 2019; Al- Qeisi, 2015; Alshehri, 2012; Venkatesh et al, 2003). In the usage of the PPS, users must perceive that the system can help improve their productivity, efficiency and accuracy in accessing data and other relevant information. 
The GPHA and the government should always embark on education for the users of the PPS to increase their usage. Amongst the original UTAUT independent constructs adopted for this study, PE had the strongest antecedent of $\mathrm{BI}$ and this finding is also consistent with the original UTAUT studies conducted by (Venkatesh et al., 2003).

The relationship between $\mathrm{EE}$ and $\mathrm{BI}$ is consistent with current literature (Osei-Owusu, et al, 2020; Obediat, 2015; Venkatesh et al, 2003). The use of the PPS come with much ease and comfortability hence leading to higher patronage. Attuquayefio (2019), Wiafe et al (2019) and Mohammad et al (2018) have all shown a positive relationship between FC and BI to use IS. This study confirms this relationship as well. When GPHA collaborate very well with the government of Ghana to provide good technical and physical infrastructural at the ports, this will go a long way to increase users of the PPS and this will help the government and other relevant stakeholders to recoup their investment made at the ports.

The relationship between trust and $\mathrm{BI}$ to use IS have been addressed by many studies and the findings of this study is consistent with their results (Alshehri 2012; Hung et al, 2006). A plausible explanation of this result can be that because the entire PPS software is been managed by the government and GPHA, users have so much trust in its usage and besides they also trust that the information put on the system cannot be manipulated by any individual or group of persons.

The relationship between SK of the PPS and ST were all not significant. These findings confirm a current study conducted by Amegboe (2019) at the ports of Ghana. In the said study both employees' knowledge of the PPS and training were not significant to influence usage of the PPS. This study also confirms existing literature (Osei-Owusu et al, 2020; Athenjia, et al., 2020).

The relationship between $\mathrm{BI}$ and $\mathrm{AU}$ have equally been addressed by many research studies and the findings of this study is consistent with their results (Osei-Owusu et al., 2020; Ofori and Nimo, 2019). As opined by Wiafe et al (2019), there are instances where people form intentions before embarking on an activity and also there are instances where individuals embark on an activity without necessarily forming any intention. The PPS has no alternative in terms of usage at the ports of Ghana. As one decides to clear goods from the ports of Ghana, the intention is formed and since there are no alternatives, the BI formed must lead to AU of the PPS in the clearance of the goods.

Theoretically, this study has validated the UTAUT model to depict an African need infused with stakeholder concept. As opined by Wiafe (2019), there is scarcity of literature and non availability in Africa and for that matter, Ghana in the area of information systems (IS) and information technology (IT) within the ports and harbor sector to explain information technologies. This study therefore, contributes to the scarce literature that currently exists at the shipping industry in Ghana and augments the knowledge and literature of IT/IS technology.

Practically, the study has also shown that the involvement of stakeholders before the implementation of any policy at the ports of Ghana will result in their full complement and support. Secondly, this study has also shown that port transactions or business can practically be done by its users without so much human interference or middle men. The new PPS makes doing business at the ports less easy since users can sit at the comfort of anywhere to assess the system.

Finally, the study was conducted at Tema harbor which happens to be the biggest seaport in Ghana. Although, Ghana has two seaports namely; Tema and Takoradi. A thorough study at both ports will help to make an informed generalization. The study is cross-sectional, that is 
to say data was collected once from the Tema port. A longitudinal study at both ports will better help in explaining the casual relationship between the variables.

\section{References}

Abu-Shanab, E., \& Pearson, J. M. (2009). Internet banking in Jordan: An Arabic instrument validation process. Int. Arab J. Inf. Technol., 6(3), 235-244.

Ajzen, I. (1991). The theory of planned behaviour. Organizational Behaviour and Human Decision Processes, 50(2) 179-211.

Alshehri, M. (2012). Using the UTAUT model to determine factors affecting acceptance and use of e -government services in the United Kingdom of Saudi Arabia. Doctoral dissertation, Griffith University.

Al-Qeisi, K. (2015). Analyzing the use of UTAUT model in explaining an online behaviour: Internet banking adoption. Doctoral dissertation, Brunel University, London.

Amegboe, W. N. (2019). The introduction of the paperless system and its impact on employee performance: A study of Tema port. Master's dissertation, University of Ghana.

Atehnjia, D., Nsoh, C., \& Obeng, F. (2020). Examining the factors affecting the implementation of a paperless port system. International Journal of Engineering and Advanced Technology, 6(7), 57-61.

Attuquayefio, S. (2019). Development of a Conceptual Framework to Support ICT Adoption by Ghanaian Higher Education Students. International Journal of Education and Development using Information and Communication Technology, 15(4), 116-131.

Bagozzi, R. P. (2009). The legacy of the technology acceptance model and a proposal for a paradigm shift. Journal of the Association for Information Systems, 8, 244-254.

Belanger, F., and Carter, L. (2005). Trust and risk in e-government adoption. Proceedings of the11th Americas Conference on Information Systems, Omaha, NE, USA.

Chin, W. W. (1998a). Commentary: issues and opinion on structural equation modeling. MIS Quarterly, Vol. 22 No. 1, pp. 7-16.

Chin, W. W. (1998b). The partial least squares approach to structural equation modeling. Modern methods for business research, 295(2), pp.295-336.

Cohen, J. (1988). Statistical Power Analysis for the Behavioral Sciences, 2nd ed., Erlbaum, Hillsdale, NJ.

Churchill, G. A. Jr (1979). A paradigm for developing better measures of marketing constructs. Journal of Marketing Research, Vol. 16 No. 1, pp. 64-73.

Colesca, S. E., \& Dobrica, L. (2008). Adoption and use of e-government services: The ease of Romania. Journal of Applied Research and Technology, 6(3), 204-217.

Davis, F., Bagozzi, R., \& Warshaw, P. (1989). User acceptance of computer technology: A comparison of two theoretical models. Management Science, 35 (8) 982- 1003.

Enrique, B., Achman, N., Tulus, W., \& Ulung, P. (2017). Are government employees adopting local e-government transformation: The need for having the right attitude, facilitating conditions and performance expectancy.? Transforming Government: People, Process and Policy, Vol.11, issue: 4, pp. 621-638.

Falk, R. F., \& Miller, N. B. (1992). A primer for soft modeling. University of Akron Press.

Fornell, C., \& Lacker, D.F. (1981). Evaluating structural equation modeling for travel behavior Research. Transportation Research Part B, University of Michigan, Vol. 37 No. 1, pp. 125.

Gefen, D., Karahanna, E., \& Straub, D. W. (2003). Trust and TAM in online shopping: an integrative model. MIS Quarterly, Vol. 27 No. 1, pp. 64-85. 
Gold, A. H., Malhotra, A., \& Segars, A. H. (2001). Knowledge management: An organizational capabilities perspective. Journal of management information systems, 18(1), 185-214.

Goularte, A. D. C., \& Zilber, S. N. (2019). The moderating role of cultural factors in the adoption of mobile banking in Brazil. International Journal of Innovation Science.

Hair, J., Blake, W., Babin, B., \& Tatham, R. (2006). Multivariate Data Analysis. New Jersey, Prentice Hall.

Hair, J. F., Ringle, C. M., \& Sarstedt, M. (2013). Partial least squares structural equation modeling: Rigorous applications, better results and higher acceptance. Long range planning, 46(1-2), 1-12.

Hair Jr, J. F. (2019). Multivariate data analysis. Andover, Hampshire, United Kingdom: Cengage.

Henseler, J., Hubona, G., \& Ray, P. A. (2016a). Using PLS path modeling in new technology research: updated guidelines. Industrial Management \& Data Systems, 116(1), 2-20.

Henseler, J., Ringle, C. M., and Sarstedt, M. (2016b). Testing measurement invariance of composites using partial least squares. International marketing review.

Henseler, J., Ringle, C. M., and Sinkovics, R. R. (2009). The use of partial least squares path modeling in international marketing. New Challenges to International Marketing, Emerald Group Publishing Limited, Bingley, pp. 277-319.

Henseler, J., Ringle, C. M., \& Sarstedt, M. (2015). A new criterion for assessing discriminant validity in variance- based structural equation modeling. Journal of the Academy of Marketing Science, 43(1), 115-135.

Hung, S. Y., Chang, C. M., \& Yu, T. J. (2010). Determinants of user acceptance of the egovernment services: The case of online tax filing and payment system. Government Information Quarterly, Vol. 23 No. 1, pp. 97-122.

Hussain, M., Mollik, A. T., Johns, R., \& Rahman, M. S. (2019). M-payment adoption for bottom of pyramid segment: an empirical investigation. International Journal of Bank Marketing.

Kline, R. B. (2011). Principles and practice of structural equation modeling (5th ed., pp. 3-427). New York: The Guilford Press.

Krueger, J. (2002). The projective perception of the social world. In Handbook of social comparison (pp. 323-351), Springer, Boston, MA.

Mcknight, D. H., Choudhury, V., \& Kacmar, C. (2002). Developing and validating trust measures for ecommerce: An integrative typology. Information. System. Research. 13, 3, 334-359.

Mikalsen, K. H., Jentoft, S. (2001). From User-Groups to Stakeholders? The Public Interest in Fisheries Management. Marine Policy, 25, 281-292.

Mohamad, M. H., Mohamed, H. A-B., Lamin, K., Mohaiyadin, N. M. H., \& Mardzuki, K. (2018). Prediction of information technology and management supports on intention towards paperless among Malaysian public university staff: Pilot study. International Journal of Academic Research in Business and Social Sciences, 8(6), 1144-1153.

Montague, E. (2010). Validation of a trust in medical technology instrument. Applied ergonomics. 2010; 41:812-821.

Mwajita, M. I. (2016). The effects of the implementation of the Kenya National Electronic Single Window System on trade facilitation. Doctoral dissertation, World Maritime University. 
Naranjo - Zolotov, M., Oliveira, T., \& Casteleyns, S. (2019). Citizens' intention to use and recommend e-participation: Drawing upon UTAUT and citizen empowerment. Information Technology and People, Vol 32, Issue: 2, pp $364-386$.

Obeidat, M. A. Q. (2015). Empirical analysis for the factors affecting realization of paperless office. International Journal of Economics, Commerce and Management, 3(6), 773-792.

Osei-Owusu, J. Y., Mahmood, R., \& Sambasivan, M. (2020). E-government initiative: Port paperless operation in Ghana. 280 th lier National Conference Proceedings, pp. 4-7.

Owusu, K. K. Archibald, D., \& Abdul, S. M. (2017). Evaluation of dry port implementation in Ghana. Maritime Business Review, Vol. 2 Issue: 3, pp.261-278.

Rahi, S., Ghani, M. A., \& Ngah, A. H. (2019). Integration of unified theory of acceptance and use of technology in internet banking adoption setting: Evidence from Pakistan. Technology in Society, 58, 1-10.

Rousseau, D. M., Sitkin, S. B., Burt, R. S., \& Camerer, C. (1998). Not so different after all: A cross-discipline view of trust. Academic. Management Review, 23, 3, 393-404.

Sambasivan, M., Patrick Wemys, G., \& Che Rose, R. (2010). User acceptance of a G2B system: A case of electronic procurement system in Malaysia. Internet Research, 20(2), 169-187.

Smith, S. L., Rodriguez, A., Miller, E. D. W., \& Xu, L. (2019). The relationship between the technology acceptance model and preference for ebooks at a large research university. Library Hi Tech News, Vol. 36 Issue: 3, pp.13-15.

Straub, D. W. (1989). Validating instruments in MIS research. MIS Quarterly, Vol. 13 No. 2, pp, 147-169.

Talal, A., \& Zhang, K. (2019). Mobile learning technology acceptance in Saudi Arabian higher education: An extended framework and mixed method study. Springer, Education and Information Technologies, 24: 2127-2144.

Tan, M., \& Teo, T. S. H. (2000). Factors influencing the adoption of internet banking. Journal of the Association of Information Systems, Vol. 1 No. 5, pp. 1-44.

Urbaniak, G. C. (1997). Research randomizer, Available at: http://randomizer.org (accessed May 20, 2021).

Venkatesh, V., Morris, M. G., Davis, G. B., \& Davis, F.D. (2003). User acceptance of information technology: Toward a unified view. MIS Quarterly, Vol. 27 No. 3, pp. 42578.

Venkatesh, V., \& Zhang, X. (2010). Unified theory of acceptance and use of technology: US vs. China. Journal of global information technology management, 13(1), 5-27.

Wiafe, I., Koranteng, F. N., Tettey, T., Kastriku, F. A., \& Abdulai, J. D. (2019). Factors that affect acceptance and use of information systems within the Maritime industry in developing countries: The case of Ghana. Journal of Systems and Information Technology, 22(1), 21-45.

Xu, J., Le, K., Deitermann, A., \& Montague, E. (2014). How different types of users develop trust in technology: A qualitative analysis of the antecedents of active and passive user trust in a shared technology. APP Ergon, 45(6), 1495-1583.

Yakubu, M. N., \& Dasuki, S. I. (2018). Factors affecting the adoption of e-learning technologies among higher education students in Nigeria: A structural equation modelling approach. Information Development, Vol. 35 No. 3, pp, 492-502. 